\title{
Cultivation of Students' Innovative Thinking in Ideology Research Learning from the Perspective of Needs Theory
}

\author{
Yuanjun Huang \\ Yichun Vocational Technology College, Yichun 336000, China \\ nior_0417@sina.com
}

\begin{abstract}
Ideology education in Universities is based on college students. According to the requirements of the development of the times and the actual situation of the change and formation of people's thought and behavior, this paper discusses the application of need theory in Ideology education in Universities. The effect of Ideology education is composed of its own education, the satisfaction of individual needs and the satisfaction of social needs. The needs of college students are closely related to the effectiveness of College Students' ideology education. Therefore, the fundamental significance and value of modern education lies in cultivating and training students' innovative spirit, forming innovative ability, and shaping students' healthy and upward personality to meet the requirements of the times. This paper aims to improve the purpose of ideology education for college students by understanding their basic needs. Meet the reasonable needs of college students and enhance the reality of ideology education; Guide the high-level needs of college students and enhance the orientation of ideology education of college students; Respecting the different needs of college students and improving the pertinence of college students' ideology education.
\end{abstract}

Keywords: Need Theory; Ideology; Research Study; Innovative Thinking.

\section{Introduction}

We are in an era when knowledge economy is beginning to take shape. It is an era based on knowledge, focusing on innovation and practice, and an era of people-oriented, personality and diversity [1]. Ideology education in universities is an education dominated by college students. According to the requirements of the development of the times and the actual situation of the change and formation of people's thoughts and behaviors, this paper discusses the application of need theory in Ideology education in Universities. The effect of ideology education consists of its own education, the satisfaction of individual needs and the satisfaction of social needs [2]. It is of great theoretical and practical significance to make students change from passive learning to active learning and enhance the effectiveness of Ideology theory teaching in universities [3]. Research-based learning is a relatively new topic in China [4]. The needs of college students are closely related to the effectiveness of ideology education of college students [5]. The rise of network media can provide more diversified means and ways for college students' ideology education, but at the same time, it should be noted that this new situation also brings some challenges to college students' ideology education [6]. Today, with the in-depth development of basic education reform, the teaching contents and methods of ideology courses in senior high schools have undergone many reforms and innovations, which have played an important role in improving the level of Marxist theory of senior high school students and positively understanding the socialist reform and development [7].

Therefore, the fundamental significance and value of modern education lies in cultivating and training students' innovative spirit, forming innovative ability, and shaping students' healthy and upward personality to meet the requirements of the times. The traditional ideology education of college students often pays more attention to its own education and its satisfaction to social needs, but does not pay enough attention to the satisfaction of College Students' personal needs. College students are high-quality groups in society, the hope of the motherland and the future of the nation [8]. To make college students become qualified builders and successors of the cause of socialism with Chinese characteristics, we should not only continuously improve their scientific and cultural qualities, but also vigorously improve their ideology qualities. As a brand-new teaching idea and 
Volume 3 (2021)

strategy, research-based learning focuses on cultivating students' autonomy, inquiry and creativity, which meets the requirements of quality education and is conducive to the lifelong development of students and the improvement of teachers' quality. The application of needs theory in ideology education in universities should play its due role. The research background and purpose of this paper will be discussed in detail below.

\section{An Overview of Marx's Need Theory}

\subsection{Connotation of Need}

The category of need plays an important role in the process of Marx's construction of his historical materialism and surplus value theory. At the same time, it is also the logical starting point of Marx's theory of man's all-round development. The need in a broad sense refers to the living state of all living things (biology, human and Society). The living things are different from the inanimate things. Their survival and development always maintain a certain exchange relationship with the external environment, and this exchange relationship is expressed as the need of organisms. In most ancient Chinese thinkers, desire often represents the evil side. At this time, the discussion of needs is usually related to the discussion of people's moral conscience. In a narrow sense, needs refer specifically to people's needs. People's needs refer to the psychological response to the object conducive to their own existence and development. It is people's love, expectation and demand for external things for survival and development. At present, many scholars and educators have paid attention to the research-based learning in the teaching of ideology courses in senior high schools. However, due to various factors, the application of research-based learning in the teaching of ideology courses in senior high schools is still at the initial exploration stage, and it has been unable to achieve a qualitative leap. Research-based learning involves the harmony and unity of students and teachers' guidance, classroom teaching and extracurricular development. The whole process is divided into three stages, namely, preparation stage, implementation stage and summary stage. The process of teaching mode of research study course. As shown in Figure 1.

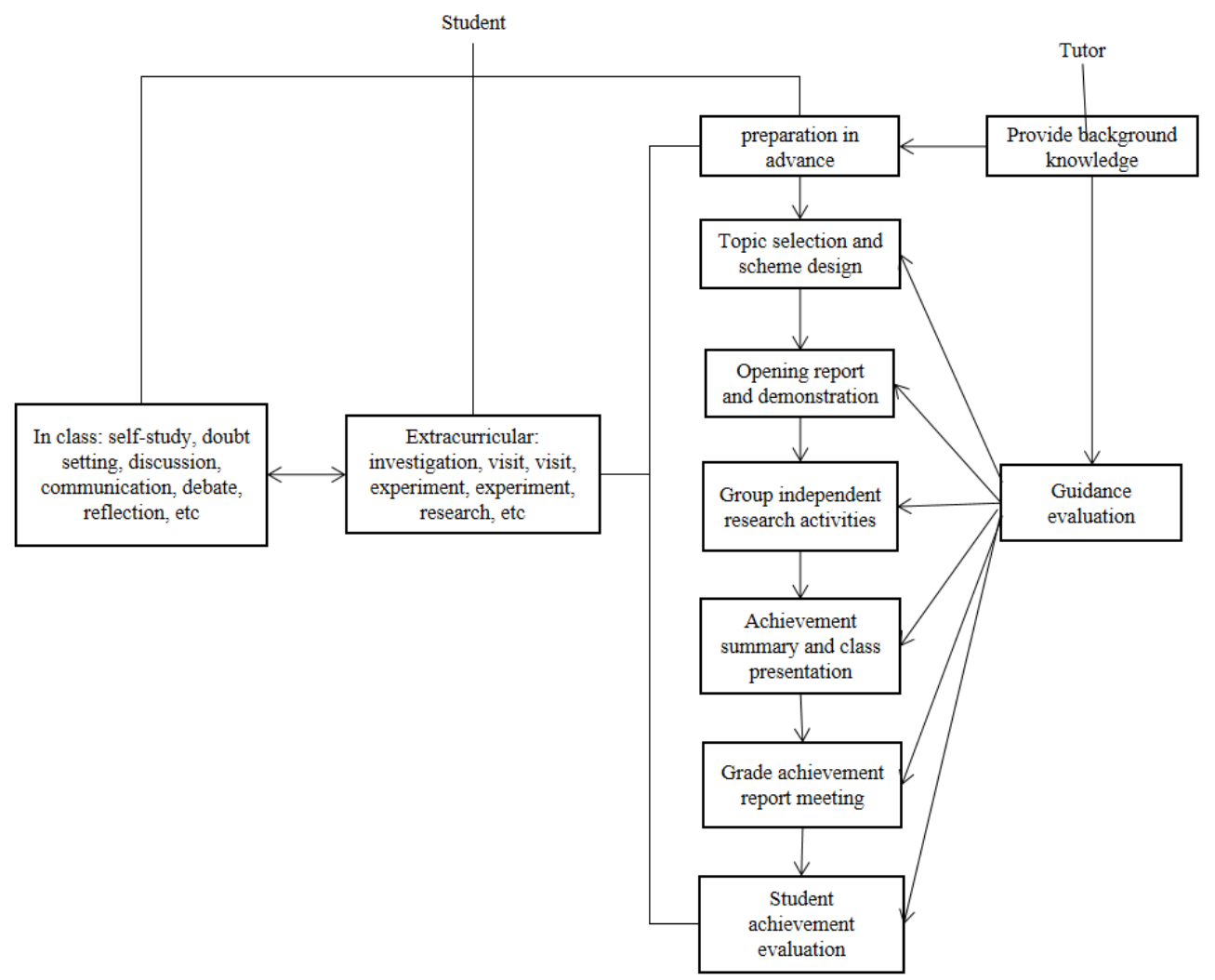

Figure 1. Process of teaching mode of inquiry learning course 
Volume 3 (2021)

It should be said that these definitions have their rationality, but there are also unscientific ones. For example, taking people's needs only as a subjective reflection, comparing people's needs with their desires, thus taking needs as purely subjective things, fundamentally negating the objectivity of needs. Once need appears, it will become a power to dominate behavior to seek satisfaction and promote people to engage in various activities. In the activities, the needs are constantly met and new needs are constantly generated, to promote the continuous development of human activities.

\subsection{Required Characteristics}

Human needs are objective. Whether they are realized or not, they are an objective existence. First, the person who needs the subject itself is an objective existence. Human needs are different from the instinctive needs of animals. Human needs are not only an instinctive reflection of human physiological activities, but also a psychological state of human experience. Under the stimulation of external factors, people will have some needs. When the needs have not been met, people will have a nervous psychological emotion, and then form an internal driving force, that is, motivation. The object of people's needs must point to the objective existence in the real society, instead of pointing to something illusory. Finally, people's way to meet their needs-practice-is also an objective material activity. The subject of practice-people, the object of practice-the material world, and the means and tools of practice are all objective. The difference of needs means that the needs of different individuals are different at different stages. This difference is not only determined by the difference of the whole human practice, but also influenced by the characteristics of different individuals. People can not only realize their own needs, but also transform their own needs according to the actual situation, especially spiritual needs and social needs, that is to say, people have great plasticity. In the process of participating in different social practice activities, people are bound to exchange with the outside world in a certain form. In the process of this exchange, new relationships between people, between people and nature and between people and society will be formed.

\section{Problems and Their Causes in the Application of Theory in Ideology Education in Universities}

\subsection{Problems in the Application of Need Theory in Ideology Education in Colleges and Universities}

There are some problems in the application of the need theory in ideology education in universities, including that the pertinence of ideology education in universities is not suitable for the actual needs of college students, and there is a certain gap between educators' own quality and the development needs of college students. At present, the ideology education of college students in China has achieved certain results and played an important role in promoting the healthy development of students and maintaining social stability. Although the Internet can bring joy and excitement for a while, it is easy to make college students feel confused, empty and bored for a long time, and even lead to psychological problems. All kinds of bad information and thoughts on the Internet will also have a certain impact on the thoughts and spirits of college students. From the personal level, the university stage is the key stage of independent growth. If the ideology education cannot well guide college students to establish a healthy and upward attitude towards life and solve many puzzles and contradictions in their life, it is bound to affect their personal development and future. The information release system is an important part of the ideology theory module. The information release system mainly includes a number of sub modules. The functions and division of labor of each module interact with each other, actively cooperate and cooperate, and realize the perfect and feasible web scheme design. The published content is shown in Figure 2. 
Volume 3 (2021)

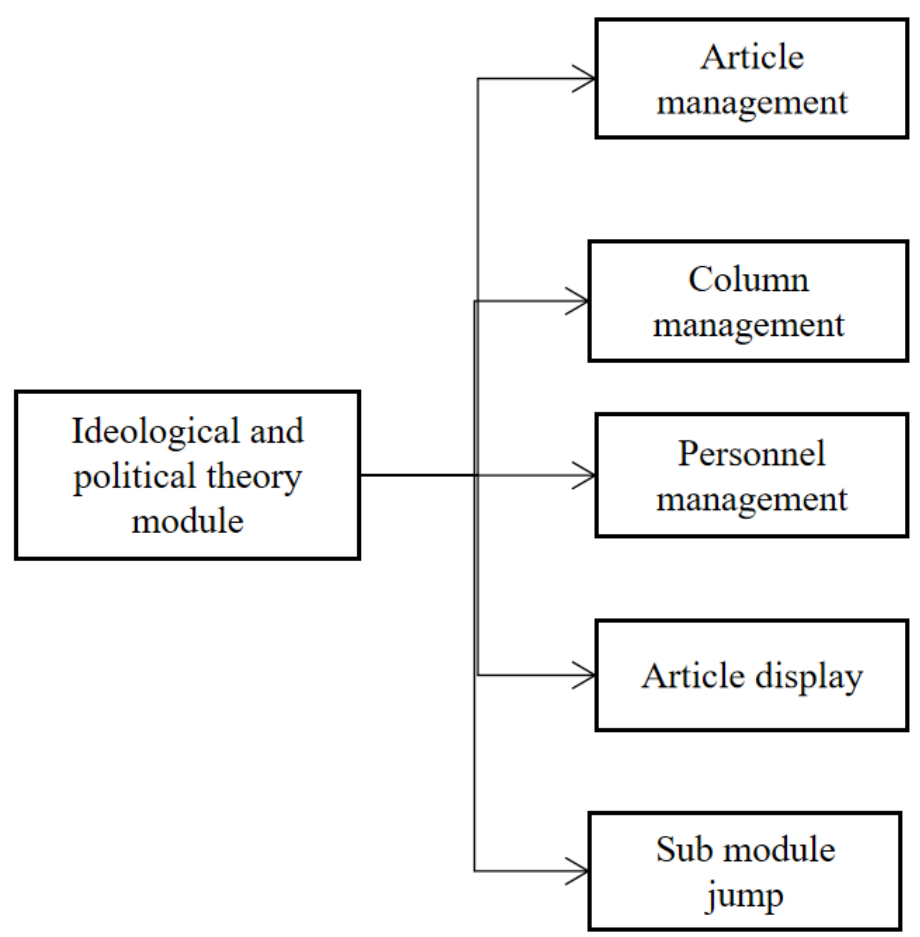

Figure 2. Ideology theory module

There are still several problems in the application of needs theory in Ideology education in Universities. Only by paying attention to relevant problems and deeply analyzing the causes of the problems, can we lay a solid foundation for the scientific application of needs theory in Ideology education in Universities, and the improvement of the effectiveness of Ideology education in Universities become possible. The competition of market economy and the invasion of Western individualism have spread the bad ideas of utilitarianism, money worship and egoism among contemporary college students, resulting in the increasing utilitarianism of college students. If the ideology education of college students is not done well, it will not only fail to realize the original intention of cultivating high-quality talents, but also cause more serious social contradictions and conflicts and affect the development of a harmonious society.

\subsection{Causes of Problems in the Application of Need Theory in Ideology Education in Colleges and Universities}

On the operational level, ideology education in universities still emphasizes the dominant position of educators, but does not pay enough attention to the subjectivity of college students, which leads to the fact that educators cannot carry out ideology education according to the real needs of college students. Most college students join the party for utilitarian purposes, but the political beliefs that should be the main motivation have been ignored by many college students. At present, there are some unsatisfactory places in the ideology education of college students. In order to seek a good strategy to effectively improve the effectiveness of the ideology education of college students, it is necessary to prescribe the right medicine, and it is possible to get twice the result with half the effort by recognizing the root of the disease. Attach importance to social needs and ignore individual needs; Attach importance to the role of college ideology education in promoting social development, while ignoring the role of college ideology education in promoting college students' personality development. The phenomenon of utilitarianism and materialization has begun to spread among college students. How to carry out relevant education for college students so that college students can reasonably pay attention to utilitarianism and material without ignoring their own spiritual and moral construction is a problem faced by college students' Ideology education. For college students whose 
discrimination ability is not firm and their ideas are not mature, they are the primary object attacked by Western cultural trends and values. College students blindly advocate western social freedom, democracy and human rights, resulting in a crisis in their political beliefs and ideals, and affecting the formation of their world outlook, outlook on life and values. Therefore, it is impossible to stimulate the enthusiasm and initiative of college students to participate in educational activities, which reduces the pertinence and weakens the effect of ideology education in universities.

\section{Conclusion}

At present, China's politics, economy and culture have changed by leaps and bounds. The effectiveness of College Students' Ideology education is the realization and degree of its social value and individual value. To judge whether the value of College Students' Ideology education is realized and its degree of realization depends on the extent to which college students' Ideology education meets social and individual needs. Need theory is an important psychological basis of Ideology education. Starting from need theory, studying the effectiveness of Ideology education has important theoretical and practical significance. As a new thing, research-based learning has greatly changed the presentation form of teachers' teaching content and students' learning methods. It is the motive force and source of people's behavior in need. It is consistent with the goal of ideology education in universities to carry out education based on the needs of college students and cultivate high-quality college students who meet the needs of social development. This paper analyzes the necessity of matching needs theory with the actual effect of ideology education of college students, and holds that needs theory provides a theoretical basis for the research of ideology education of college students, and helps to better understand the educational objects and optimize the functions of the whole ideology education system.

\section{References}

[1] Luo Jing. On the construction of the three-stage mode of research learning in the ideology theory course-Taking the "Outline of Modern Chinese History" as an example[J]. Educational Observation, 2018, 007(001): P.75-76.

[2] Lian Jianbin. Practical exploration of research-based learning in ideology theory courses in universities[J]. Journal of Harbin Vocational and Technical College, 2017(06):66-68.

[3] Xu Ping. Research on the Application of Research Learning in University Ideology Theory Teaching[J]. 2021 (2011-5):52-55.

[4] Yang Zezhang, Bai Xueshuang. The practice and innovation of the teaching reform of ideology theory courses for graduate students: an analysis based on the perspective of research learning [J]. Ideology Course Research, 2019, 000(005): 69-73.

[5] Jiang Huailiu, Xie Xiujun. The research study of ideology theory under the guidance of system theory[J]. School Party Building and Ideological Education, 2017, 000(009): 17-19.

[6] Wang Tingting, Liao Yaqin. Research on the Construction of Research Learning Mode for College Students' Ideology Theory Courses[J]. Journal of Hunan University of Science and Technology, 2020 (2): 4-6.

[7] Qiu Yongmin. Introducing research-based learning paradigm to improve the effectiveness of the teaching of ideology theory courses in universities[J]. Research on Ideology Courses, 2018, No.232(04):38-41.

[8] Sun Bin. Research on the Research Study Mode of Ideology Theory Courses in Higher Vocational Colleges [J]. Youth Years, 2019, 000(011):190-191.

[9] Peng Xiao. Research study of ideology theory courses in universities [J]. Education, 2016, 000(023): 6061. 